\title{
Detection of lamprey in Southernmost South America by environmental DNA (eDNA) and molecular evidence for a new species
}

\author{
Cristina Fernanda Nardi ${ }^{1}$ ([) Julieta Sánchez ${ }^{1,2}$ (D) Daniel Alfredo Fernández ${ }^{1,3}$ - Miguel Ángel Casalinuovo ${ }^{4}$. \\ Javier Hernán Rojo $^{3}$ (i) $\cdot$ Tomás Chalde ${ }^{3,5}$ (i)
}

Received: 25 February 2019 / Revised: 18 February 2020 / Accepted: 26 February 2020

(c) Springer-Verlag GmbH Germany, part of Springer Nature 2020

\begin{abstract}
Lampreys are jawless fishes belonging to the order Petromyzontiformes. Geotria australis is the sole representative lamprey species of the Geotriidae family and is widely distributed around South America, Australia, New Zealand, and sub-Antarctic Islands. In South America, the presence and distribution of G. australis are well characterized in Western Patagonia, in rivers flowing into the Pacific Ocean. In contrast, there is scarce information about the presence of this species in Eastern Patagonia, in rivers flowing into the Atlantic Ocean. Here, we provide the first report on the distribution of lamprey at the extreme south of Patagonia and suggest the occurrence of a new lamprey species. We developed an environmental DNA (eDNA) method to detect $G$. australis from water samples and obtained positive results in five basins flowing into the Atlantic Ocean and one river basin flowing into the Beagle Channel. Lampreys were captured from two eDNA-positive basins and used for genetic analysis. An 875 bp-sequence of the cytochrome b mitochondrial gene was obtained, and a phylogenetic analysis was carried out with this sequence and those available in GenBank, revealing Argentinean lamprey reported here, as a sister species of G. australis from Chile, Australia, and New Zealand. Also, the genetic distance values between lamprey reported here and G. australis were consistent with the genetic distances between species of different genera. Our results suggest that the Argentinean lamprey corresponds to a new specific taxon that could represent a new monotypic genus in Geotriidae.
\end{abstract}

Keywords Sub-antarctic fishes $\cdot$ Patagonia $\cdot$ Tierra del fuego $\cdot$ Freshwater fishes $\cdot$ Native species $\cdot$ Petromyzontiformes . Environmental DNA

Electronic supplementary material The online version of this article (https://doi.org/10.1007/s00300-020-02640-3) contains supplementary material, which is available to authorized users.

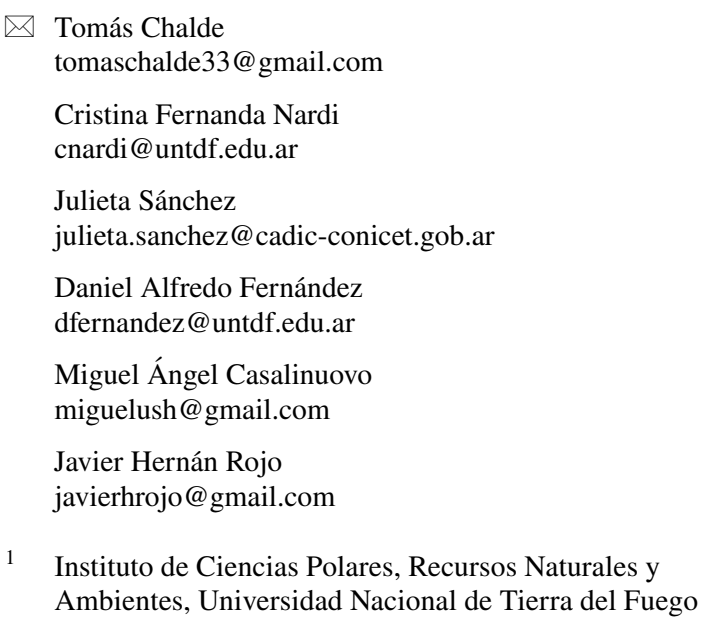

Ambientes, Universidad Nacional de Tierra del Fuego

(ICPA-UNTDF-CONICET), Fuegia Basket 251, V9410 Ushuaia, Argentina

2 Laboratorio de Ecología Molecular, Centro Austral de Investigaciones Científicas (CADIC-CONICET), Bernardo A. Houssay 200, V9410 Ushuaia, Argentina

3 Laboratorio de Ecología, Fisiología y Evolución de Organismos Acuáticos, Centro Austral de Investigaciones Científicas (CADIC-CONICET), Bernardo A. Houssay 200, V9410 Ushuaia, Argentina

4 Freelance Biologist, Sarmiento 499, X5111 Río Ceballos, Argentina

5 Facultad Regional Tierra del Fuego, Universidad Tecnológica Nacional, Perito Moreno 1425, V9410 Ushuaia, Argentina 


\section{Introduction}

Lampreys are jawless fish belonging to the order Petromyzontiformes, which comprise 40-45 species, depending on the author (Renaud 2011; Maitland et al. 2015; Potter et al. 2015). Lampreys are widely distributed in both hemispheres and are generally found in cold waters (Renaud 2011). In the Southern Hemisphere, only the Mordaciidae and Geotriidae families have been reported. Mordaciidae family includes three species: Chilean lamprey (Mordacia lapicida), short-headed lamprey (M. mordax) and precocious lamprey (M. praecox); while a unique species represents Geotriidae family: pouched lamprey (Geotria australis), widely distributed around Australia, New Zealand, South American Patagonia and sub-Antarctic Islands (McDowall 2002).

In South America, the distribution and life history of lampreys have been documented in rivers flowing into the Pacific Ocean, finding G. australis and M. lapicida in Western Patagonia (Chile). The latter is recognized as an endemic species of this region (Neira 1984; McDowall 1988; Habit et al. 2007). On the other hand, little is known about the presence and distribution of lampreys in Eastern Patagonia (Argentina), in rivers flowing into the Atlantic Ocean (Fig. 1a). In this regard, few studies describe some aspects of the morphology and life history of lampreys in this region, and only the presence of $G$. australis has been reported (Neira et al. 1988; Azpelicueta et al. 2001). Although G. australis presence has been reported in Western and Eastern Patagonia, several studies have described morphological differences between both populations (Neira et al. 1988; Renaud 2011; Potter et al. 2015). Besides, a cluster analysis based on body measurements from G. australis in larval stage performed by Neira et al. (1988) separated the Argentinian population from those of Chile, New Zealand, Tasmania, and Australia.

Argentinean section of Tierra del Fuego Island (TDF; $52^{\circ} \mathrm{S}-55^{\circ} \mathrm{S}$ ) is located at the extreme south of Patagonia with rivers flowing into the Atlantic Ocean to the East, and into the Beagle Channel to the South (Fig. 1b). Freshwater environments of TDF have the lowest native fish biodiversity of all Patagonia (Cussac et al. 2009), with only two native species: small puyen and big puyen (Galaxias maculatus and G. platei, respectively) (Cussac et al. 2016). On the other hand, several exotic salmonids such as rainbow trout (Oncorhynchus mykiss), brown trout (Salmo trutta), brook trout (Salvelinus fontinalis), chinook salmon (O. tshawytscha), and coho salmon (O. kisutch) have been introduced and established in TDF (Pascual et al. 2007; Chalde et al. 2019; Nardi et al. 2019). These exotic species might compete for space and food with native species and are considered a possible threat for native ecosystems (Pascual et al. 2002, 2007).
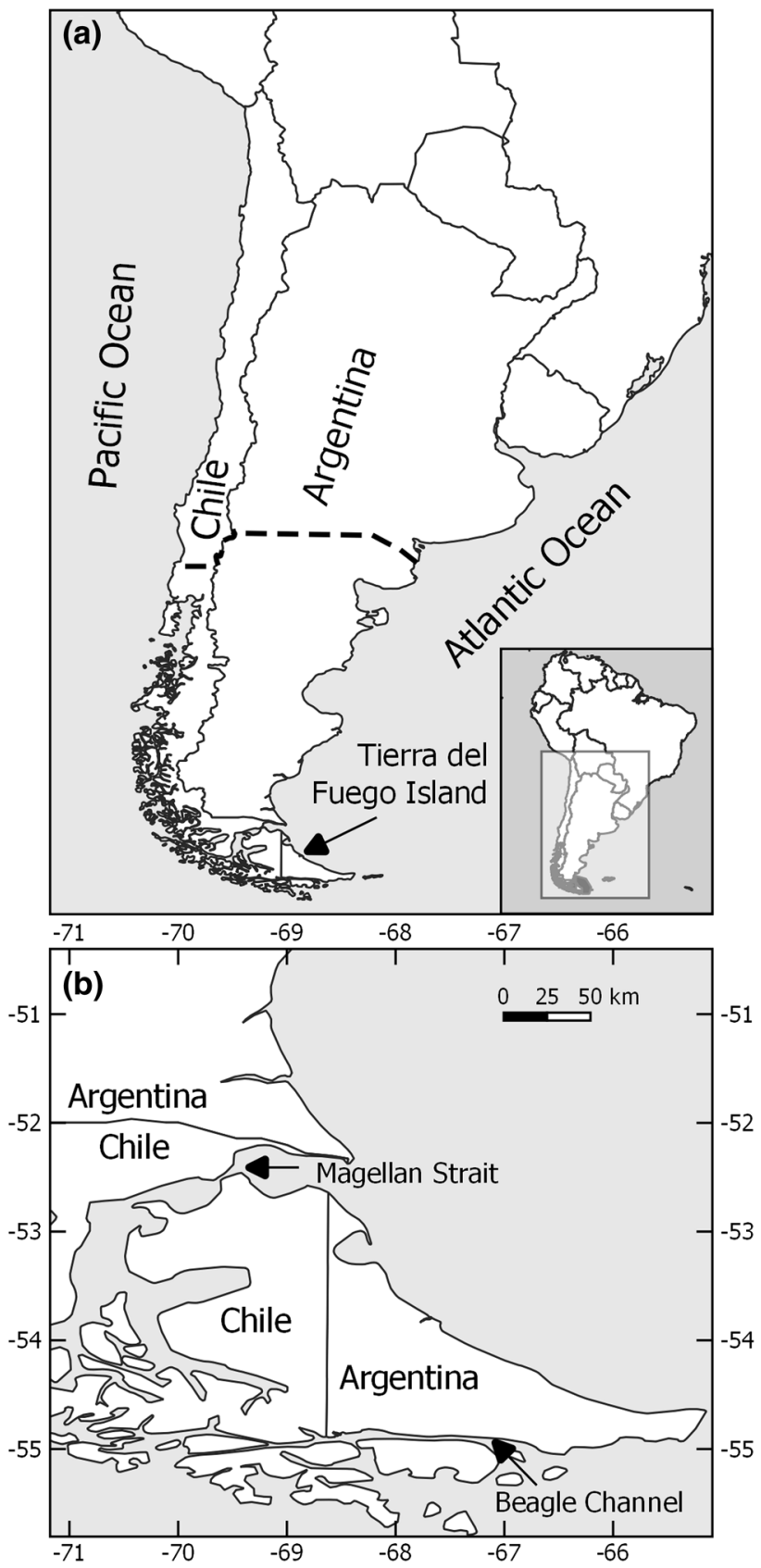

Fig. 1 Study area showing a Northern limit of Patagonia Region (dashed line) and, b Tierra del Fuego Island at the extreme south of Patagonia. Map created using QGIS 3.0.3 software

The knowledge of species presence and distribution is critical to developing management and conservation actions (Stem et al. 2005). However, one major limitation when determining the distribution of species by using conventional fishing gear (e.g., nets, traps, electrofishing, angler records) is the low detection rate of uncommon or endangered species because they are rare in the wild by definition, and also because detection requires taxonomic skills to identify them (Laramie et al. 2015; Mizumoto et al. 2017). 
Environmental DNA (eDNA) is a relatively new approach used to detect the presence of species, even at low densities. Using this method, it is possible to detect species without actually seeing or catching them (Taberlet et al. 2018). The eDNA-based method has been successfully applied in several groups of aquatic species, such as amphibians (Evans et al. 2016), reptiles (Raemy and Ursenbacher 2018), and also fish (Roy et al. 2018). In this regard, several studies have used eDNA-based methods to detect different species of lampreys from water samples (Knebelsberger et al. 2014; Carim et al. 2016; Gingera et al. 2016; Bracken et al. 2019). Besides, since eDNA-based methods are a non-invasive tool, several works have been focused on the detection of endangered species using this approach (Carim et al. 2016; Mizumoto et al. 2017; Fernandez et al. 2018).

This study aims to gain insight into the presence and distribution of lampreys in Southernmost Patagonia, in rivers flowing into the Atlantic Ocean, where lampreys have been poorly studied, and in rivers flowing into the Beagle Channel, where the presence of lampreys have never been reported before. This work also expects to open the discussion on the possibility that G. australis is not the only lamprey species in Argentinean Patagonia, as previously reported.

\section{Materials and methods}

\section{Bibliographic review}

Due to the scarce information on the presence and distribution of lampreys in Patagonia, a bibliographic search was performed to review the available data in this region. An extensive literature search was carried out using Google Scholar covering all full publications in English and Spanish language between 1900 and 2018. A search strategy including a combination of keywords 'lamprey distribution Patagonia', 'lamprey distribution South America', and 'freshwater fishes Patagonia' was applied. All publications and their references were analyzed. Only publications where the lamprey captures and specific location were documented, were summarized. Neither personal communications nor unpublished data were considered as reliable records of lamprey.

\section{Lamprey detection by eDNA}

\section{Primers design and validation}

Two sets of primers were designed on the mitochondrial genome of G. australis using Primer 3.0 software (Koressaar and Remm 2007; Untergasser et al. 2012). For this, a sequence reported by Ren et al. (2016) obtained from an individual captured at the Oreti River, New Zealand, was used (Accession Number NC_029404). A set of primers was designed on the cytochrome $b$ gene (cyt b) $(10,431-11,606 \mathrm{bp})$ and the additional set on the cytochrome oxidase subunit I (COI) gene (1-1554 bp) (Table 1). To assess the reliability and specificity of the primers, an in silico and in vitro validation was performed, according to Nardi et al. (2019) (Online Resource 1). In brief, the in silico analysis was performed using the primer BLAST tool of the NCBI (www.ncbi.nlm.nih.gov//tools/primer-blast) and included all the species reported at the area: big and small puyen, chinook salmon, coho salmon, rainbow trout, brown trout, and brook trout (Cussac et al. 2016; Chalde et al. 2019; Nardi et al. 2019). Although not observed since reported by Moreno and Jara (1984), the galaxiids fish Aplochiton taeniatus and A. zebra were also included in the in silico analysis. For in vitro validation, total DNA was obtained from two lampreys (Lamprey 1 and 2) captured in Grande river basin (Menéndez River, TDF) in April 2015 and used as target DNA. Total DNA was also extracted from all the observed co-occurring non-target species (all the mentioned above, except for Aplochiton spp). Total DNA was extracted from muscle tissue using a DNeasy Blood and Tissue Kit (Qiagen, Germany), following the manufacturer's protocol. A dilution of $35 \times 10^{-4} \mathrm{ng} \mu \mathrm{L}^{-1}$ was used for target and non-target templates in the specificity analysis, and four controls were established to check for cross-amplification. The amplification reactions were performed in triplicate by Real-Time PCR using a Step One Real-Time PCR System equipment (Applied Biosystems, USA) in a total volume of

Table 1 Set of primers designed on Geotria australis sequence reported by Ren et al. (2016), obtained from an individual captured at the Oreti River, New Zealand (Accession Number NC_029404)

\begin{tabular}{|c|c|c|c|}
\hline Target gene & Forward primer $5^{\prime}-3^{\prime}$ & Reverse primer $5^{\prime}-3^{\prime}$ & $\begin{array}{l}\text { Amplicon } \\
\text { length } \\
\text { (bp) }\end{array}$ \\
\hline Cytochrome b (cyt b) & CCTACATACATCTCAACAA & GGTATTCTACTGGTTCAC & 119 \\
\hline $\begin{array}{l}\text { Cytochrome c oxidase subunit } \\
\text { I (COI) }\end{array}$ & CCTCGTTCGTTGATTATTCTCC & GTTGGCTTAGTTCTGCTCGAAT & 125 \\
\hline
\end{tabular}

The cyt b primers did not amplify DNA of lampreys from Eastern Patagonia. The COI set of primers was further used for eDNA amplification 
$15 \mu \mathrm{L}$; including $1 \times$ iTaq SYBR Green Supermix (Bio-Rad, USA); $0.85 \mu \mathrm{M}$ of each primer and $1 \mu \mathrm{L}$ of each template. Cycling conditions included a first denaturation step at $95^{\circ} \mathrm{C}$ for $10 \mathrm{~min}$ and 40 cycles of a denaturation step at $95^{\circ} \mathrm{C}$ for $15 \mathrm{~s}$ and an annealing/extension step at $60^{\circ} \mathrm{C}$ for $1 \mathrm{~min}$, followed by a melting curve from $60{ }^{\circ} \mathrm{C}$ to $95{ }^{\circ} \mathrm{C}$ at $0.3{ }^{\circ} \mathrm{C}$ increments. A cycle threshold $\left(C_{\mathrm{t}}\right)$ analysis was performed, and PCR products were visualized in $2 \%$ Low EEO agarose gels. The sequences obtained in the positive and specificity control were verified at the Macrogen Korea sequencing service.

\section{Water sampling and eDNA extraction}

A total of 21 environmental water samples were collected during early spring 2017 (September-October) with sterile bottles (1 L per site). Sample sites included seven basins flowing into the Atlantic Ocean and five basins flowing into the Beagle Channel (Fig. 2, Table 2). All of these rivers are located on the Argentinean section of the Island of TDF, except for Gallegos basin, which is the more austral basin in the continental region of Argentina. Water samples were maintained at $4-8{ }^{\circ} \mathrm{C}$ and filtered within the next $24 \mathrm{~h}$ using disposable sterile filter units of cellulose nitrate of $0.45-\mu \mathrm{m}$ pore size until the full volume passed through. Filters were stored individually at $-80{ }^{\circ} \mathrm{C}$ until DNA extraction. eDNA was extracted using QiaShredder and Qiagen's DNeasy Blood \& Tissue Kits (Qiagen GmbH, Germany) following the manufacturer's protocol with minor modifications, according to Goldberg et al. (2011). The extractions were done under sterile conditions in a laboratory unit exposed periodically to UV-light and where no other tissue samples were manipulated. One liter of milliQ water was filtrated, the eDNA extracted and further included in all analyses to confirm that contamination did not take place during filtration or eDNA extraction.

\section{eDNA samples analysis}

Environmental samples were analyzed for the possible presence of inhibitors of the PCR reaction, according to Goldberg et al. (2016). In brief, $1 \mu \mathrm{L}$ of three different dilutions $(1: 10 ; 1: 20$ and $1: 40)$ of the eDNA samples and a foreign DNA, known as "internal positive control" (IPC), were mixed in a tube. Then a PCR assay was performed to amplify the IPC. Samples were considered inhibition-free when the amplification plot of the IPC in the presence of the eDNA was comparable to that observed in the positive control (IPC without eDNA). Since eDNA samples were highly diluted (up to 1:40) to avoid inhibition, an amplification control was performed, according to Nardi et al. (2019). In brief, a fragment of $169 \mathrm{bp}$ of the ribulose-1,5-bisphosphate carboxylase ( $\mathrm{rcbl}$ ) gene of diatoms inhabiting the area was used as amplification control. Only dilutions with no signs of inhibition and positive for the amplification control were further used for lamprey presence/non-detection analysis.

\section{Lamprey detection by eDNA}

For environmental samples amplification, the COI set of primers was used. A five-point standard curve was performed with DNA of target lamprey as template, including a serial dilution from $35 \times 10^{-1}$ to $35 \times 10^{-5} \mathrm{ng} \mathrm{\mu L}^{-1}$ to estimate the amplification efficiency of the primer pair. Standard curve fitted the equation $y=-3 x+27.336 ; R^{2}=0.992$. The efficiency of primers was $85-87 \%$. Conditions of Real-Time PCR reaction were as previously described for this set of primers. Six replicates were performed per sample, including a negative water control in each run. One microliter of the diluted environmental sample was added as template. Amplification of at least two of the replicates, accompanied by a melting curve consistent with our target DNA $\left(T_{\mathrm{m}}=77.68-78.13{ }^{\circ} \mathrm{C}\right)$ and sequencing at the Macrogen Korea service, was required to identify a positive detection of lamprey. Environmental sequences were edited and aligned using BioEdit Sequence Alignment Editor (Hall 1999).

\section{Lamprey capture by electrofishing}

In order to capture lampreys for genetic analysis, electrofishing surveys were performed in April 2018 in three eDNA-positive river basins: Gallegos, Grande, and Lapataia (Fig. 3). These basins were selected in order to represent the northern, central, and southern regions of the sampled area. For morphometric analysis, lampreys were captured by electrofishing in January 2019 and 2020 from Grande River. Gallegos basin is located in the southern region of the Santa Cruz province. It crosses Chilean and Argentine territory from the Andean mountain range at the west and the Atlantic Ocean at the east $\left(51^{\circ} 35^{\prime} 59^{\prime \prime} \mathrm{S}\right)$. It occupies an area of $19,306 \mathrm{~km}^{2}$ with a mean annual flow of $39.1 \mathrm{~m}^{3} \mathrm{~s}^{-1}$ and a mean annual air temperature of $6{ }^{\circ} \mathrm{C}$ (Diaz et al. 2017). Grande basin is located in the northern region of Tierra del Fuego Province. It also crosses Chilean and Argentine territory from the Andean mountain range at west to the Atlantic Ocean at the east $\left(53^{\circ} 47^{\prime} 17^{\prime \prime} \mathrm{S}\right)$. It occupies an area of 8580 $\mathrm{km}^{2}$ with a mean annual flow of $45 \mathrm{~m}^{3} \mathrm{~s}^{-1}$ and a mean annual air temperature of $5.6{ }^{\circ} \mathrm{C}$ (Iturraspe and Urciuolo 2007). Lapataia basin is born in Chilean glaciers located in Andean mountains, crosses the Acigami Lake of $22 \mathrm{~km}^{2}$, and drains for $2 \mathrm{~km}$ across the Argentine territory, flowing into the Beagle Channel (54 $50^{\prime} 41^{\prime \prime} \mathrm{S}$ ). It occupies an area of $540 \mathrm{~km}^{2}$ with a mean annual flow of $18.7 \mathrm{~m}^{3} \mathrm{~s}^{-1}$ and a mean annual air temperature of $5.4{ }^{\circ} \mathrm{C}$ (Niemeyer 1982; Iturraspe and Urciuolo 2007). We sampled a total of 61 sites in autumn 

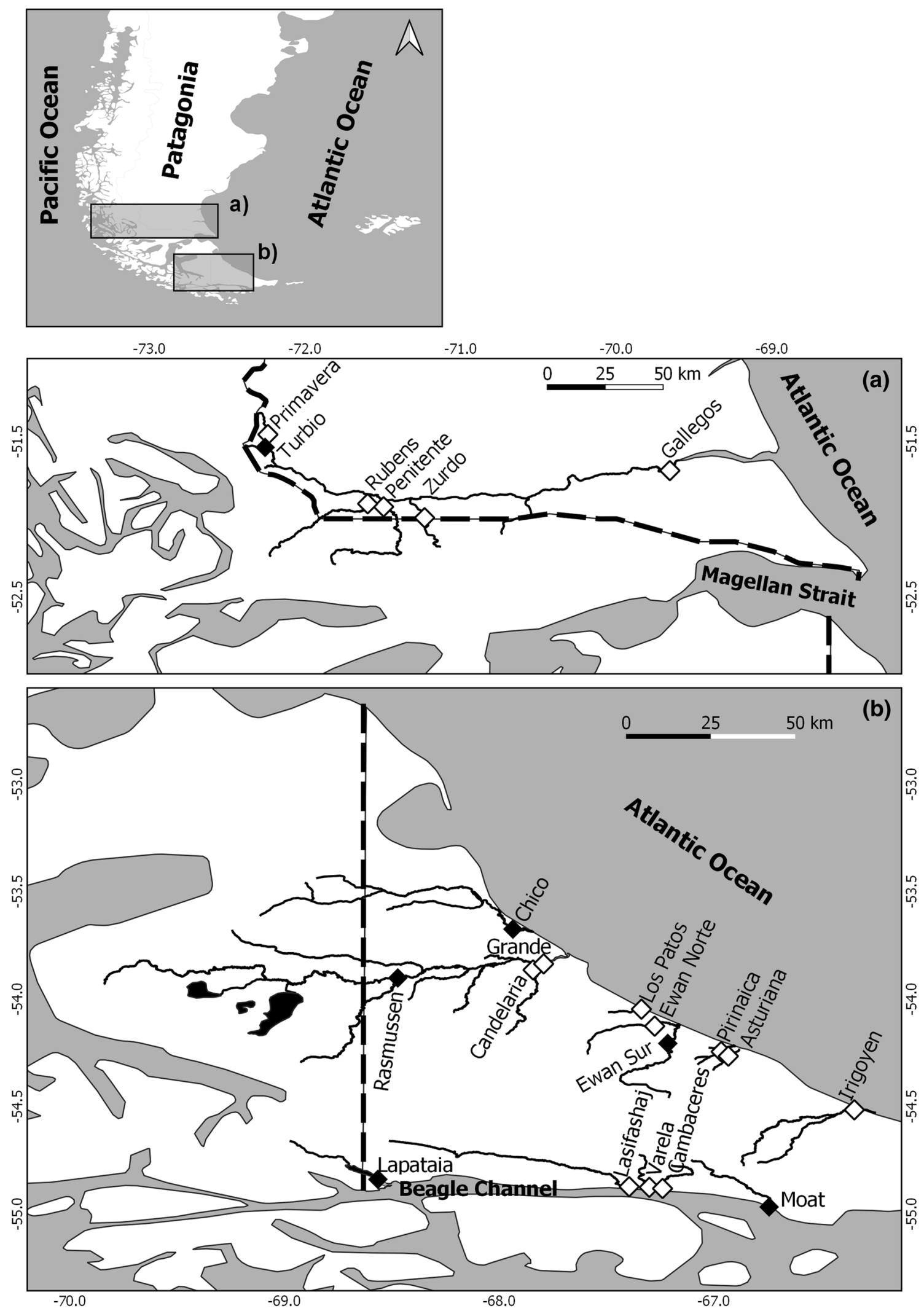

Fig. 2 Estimated presence/non-detection of lamprey in the study area based on the detection of environmental DNA (eDNA) in a Gallegos basin, Santa Cruz Province, and b Tierra del Fuego basins. Black and white squares indicate the presence and non-detection of lamprey, respectively. Dashed lines indicate the Argentine-Chilean border 
Table 2 Results of the environmental DNA-based method for detection of lamprey

\begin{tabular}{|c|c|c|c|c|c|c|c|}
\hline \multirow[t]{2}{*}{ Basin } & \multirow[t]{2}{*}{ River } & \multirow[t]{2}{*}{ Outflowing } & \multicolumn{2}{|c|}{ At the sample site } & \multirow{2}{*}{$\begin{array}{l}\text { Distance from } \\
\text { mouth }(\mathrm{km})\end{array}$} & \multirow[t]{2}{*}{ Altitude (masl) } & \multirow{2}{*}{$\begin{array}{l}\text { eDNA } \\
\text { detec- } \\
\text { tion }\end{array}$} \\
\hline & & & Latitude & Longitude & & & \\
\hline \multirow[t]{6}{*}{ Gallegos } & Primavera & Atlantic & $51^{\circ} 31^{\prime} 32^{\prime \prime} \mathrm{S}$ & $72^{\circ} 16^{\prime} 03^{\prime \prime} \mathrm{W}$ & 293 & 260 & - \\
\hline & Turbio & Atlantic & $51^{\circ} 32^{\prime} 36^{\prime \prime} \mathrm{S}$ & $72^{\circ} 14^{\prime} 01^{\prime \prime} \mathrm{W}$ & 288 & 238 & $\checkmark$ \\
\hline & Rubens & Atlantic & $51^{\circ} 54^{\prime} 11^{\prime \prime} \mathrm{S}$ & $71^{\circ} 36^{\prime} 15^{\prime \prime} \mathrm{W}$ & 205 & 115 & - \\
\hline & Penitente & Atlantic & $51^{\circ} 59^{\prime} 36^{\prime \prime} \mathrm{S}$ & $71^{\circ} 29^{\prime} 43^{\prime \prime} \mathrm{W}$ & 216 & 127 & - \\
\hline & Zurdo & Atlantic & $51^{\circ} 59^{\prime} 36^{\prime \prime} \mathrm{S}$ & $71^{\circ} 13^{\prime} 55^{\prime \prime} \mathrm{W}$ & 189 & 136 & - \\
\hline & Gallegos & Atlantic & $51^{\circ} 41^{\prime} 16^{\prime \prime} \mathrm{S}$ & $69^{\circ} 39^{\prime} 20^{\prime \prime} \mathrm{W}$ & 13 & 17 & - \\
\hline Chico & Chico & Atlantic & $53^{\circ} 40^{\prime} 25^{\prime \prime} \mathrm{S}$ & $67^{\circ} 56^{\prime} 07^{\prime \prime} \mathrm{W}$ & 10 & 6 & $\checkmark$ \\
\hline \multirow[t]{3}{*}{ Grande } & Rasmussen & Atlantic & $53^{\circ} 54^{\prime} 04^{\prime \prime} \mathrm{S}$ & $68^{\circ} 28^{\prime} 17^{\prime \prime} \mathrm{W}$ & 77 & 51 & $\checkmark$ \\
\hline & Candelaria & Atlantic & $53^{\circ} 51^{\prime} 49^{\prime \prime} \mathrm{S}$ & $67^{\circ} 50^{\prime} 28^{\prime \prime} \mathrm{W}$ & 23 & 10 & - \\
\hline & Grande & Atlantic & $53^{\circ} 50^{\prime} 10^{\prime \prime} \mathrm{S}$ & $67^{\circ} 47^{\prime} 34^{\prime \prime} \mathrm{W}$ & 15 & 6 & - \\
\hline Los Patos & Los Patos & Atlantic & $54^{\circ} 02^{\prime} 48^{\prime \prime} \mathrm{S}$ & $67^{\circ} 20^{\prime} 12^{\prime \prime} \mathrm{W}$ & 2 & 7 & - \\
\hline \multirow[t]{2}{*}{ Ewan } & Ewan Norte & Atlantic & $54^{\circ} 07^{\prime} 33^{\prime \prime} \mathrm{S}$ & $67^{\circ} 16^{\prime} 29^{\prime \prime} \mathrm{W}$ & 25 & 19 & - \\
\hline & Ewan Sur & Atlantic & $54^{\circ} 12^{\prime} 22^{\prime \prime} \mathrm{S}$ & $67^{\circ} 12^{\prime} 56^{\prime \prime} \mathrm{W}$ & 20 & 25 & $\checkmark$ \\
\hline \multirow[t]{2}{*}{ Ladrillero } & Pirinaica & Atlantic & $54^{\circ} 14^{\prime} 50^{\prime \prime} \mathrm{S}$ & $66^{\circ} 57^{\prime} 58^{\prime \prime} \mathrm{W}$ & 11 & 36 & - \\
\hline & Asturiana & Atlantic & $54^{\circ} 15^{\prime} 24^{\prime \prime} \mathrm{S}$ & $66^{\circ} 56^{\prime} 28^{\prime \prime} \mathrm{W}$ & 13 & 42 & - \\
\hline Irigoyen & Irigoyen & Atlantic & $54^{\circ} 30^{\prime} 53^{\prime \prime} \mathrm{S}$ & $66^{\circ} 17^{\prime} 38^{\prime \prime} \mathrm{W}$ & 0.4 & 4 & - \\
\hline Moat & Moat & Beagle Channel & $54^{\circ} 58^{\prime} 04^{\prime \prime} \mathrm{S}$ & $66^{\circ} 44^{\prime} 28^{\prime \prime} \mathrm{W}$ & 0.8 & 10 & $\checkmark$ \\
\hline Cambaceres & Cambaceres & Beagle Channel & $54^{\circ} 52^{\prime} 54^{\prime \prime} \mathrm{S}$ & $67^{\circ} 14^{\prime} 20^{\prime \prime} \mathrm{W}$ & 0.8 & 10 & - \\
\hline Varela & Varela & Beagle Channel & $54^{\circ} 52^{\prime} 31^{\prime \prime} \mathrm{S}$ & $67^{\circ} 18^{\prime} 08^{\prime \prime} \mathrm{W}$ & 2 & 7 & - \\
\hline Lasifashaj & Lasifashaj & Beagle Channel & $54^{\circ} 52^{\prime} 22^{\prime \prime} \mathrm{S}$ & $67^{\circ} 23^{\prime} 38^{\prime \prime} \mathrm{W}$ & 3 & 8 & - \\
\hline Lapataia & Lapataia & Beagle Channel & $54^{\circ} 50^{\prime} 32^{\prime \prime} \mathrm{S}$ & $68^{\circ} 33^{\prime} 51^{\prime \prime} \mathrm{W}$ & 0.5 & 6 & $\checkmark$ \\
\hline
\end{tabular}

(April). Among these, 23 sites corresponded to seven rivers of Gallegos basin; 19 sites corresponded to seven rivers of Grande basin, and the last 19 sites corresponded to Lapataia basin. All sites were sampled with a backpack electrofishing gear (LR-24 Electrofisher, Smith Root Inc, USA) set up at $75 \mathrm{~Hz}$ and $25 \%$ duty cycle used to produce 450-V, 75 Amps standard pulse (pulse width $-3 \mathrm{~ms}, 60$ pulses $\mathrm{s}^{-1}$ ).

\section{Lamprey DNA extraction and PCR amplification}

Total DNA from 14 lampreys was successfully extracted from muscle tissue using a DNeasy Blood and Tissue Kit (Qiagen, Germany), following the manufacturer's protocol. A PCR assay was used to amplify $1,100 \mathrm{bp}$ of the mitochondrial cyt b gene, using the primers "Geotria496L" and "Phe1612H" for Geotriidae family reported by Lang et al. (2009). A reaction mixture containing $1 \mu \mathrm{L}$ of total DNA (10 ng $\mu \mathrm{L}^{-1}$ ), 1 unit of Go Taq DNA polymerase (Promega, USA), $1 \times$ Go Taq polymerase buffer, dNTPs $(0.2 \mathrm{mM}$ of each) and forward and reverse primers (0.2 and $0.9 \mathrm{nM}$, respectively), was prepared. Cycling conditions were as follows: an initial denaturation of $5 \mathrm{~min}$ at $95^{\circ} \mathrm{C}, 40$ cycles of $30 \mathrm{~s}$ of denaturation at $94^{\circ} \mathrm{C}, 40 \mathrm{~s}$ of annealing at $51^{\circ} \mathrm{C}$, and $80 \mathrm{~s}$ of extension at $72{ }^{\circ} \mathrm{C}$, with a final extension of 5 min at $72{ }^{\circ} \mathrm{C}$. PCRs were performed in a 2720 Thermal
Cycler (Applied Biosystems, USA). Amplification products of the expected size were purified using a gel extraction kit (PuriPrep-GP; INBIO Highway, Argentina) and sequenced at Macrogen Korea service using the same primers as the amplification.

\section{Phylogenetic analysis and genetic distances}

The 14 cyt $b$ gene sequences obtained were edited, contigs were assembled and aligned using BioEdit Sequence Alignment Editor (Hall 1999). The cyt b sequences from four individuals obtained in this study were deposited in GenBank (AN MK408981-4). Also, a sequence similarity search was performed using the Basic Local Alignment Search Tool (BLAST). Then, a matrix was constructed, including 41 sequences $(875 \mathrm{bp})$ of the cyt $\mathrm{b}$ gene. From these, 38 sequences belonged to lamprey species reported by Lang et al. (2009); one sequence belonged to G. australis from New Zealand (AN NC_029404); one sequence corresponded to the cyt b sequence obtained in this study (Argentinean lamprey; AN MK408981); and one sequence was used as outgroup (Myxine glutinosa; AN AJ278504). From this matrix, a phylogenetic analysis was performed through three methods: Maximum Likelihood (ML), Bayesian Inferences (BI), and Maximum Parsimony (MP). ML analysis was carried out with the online 

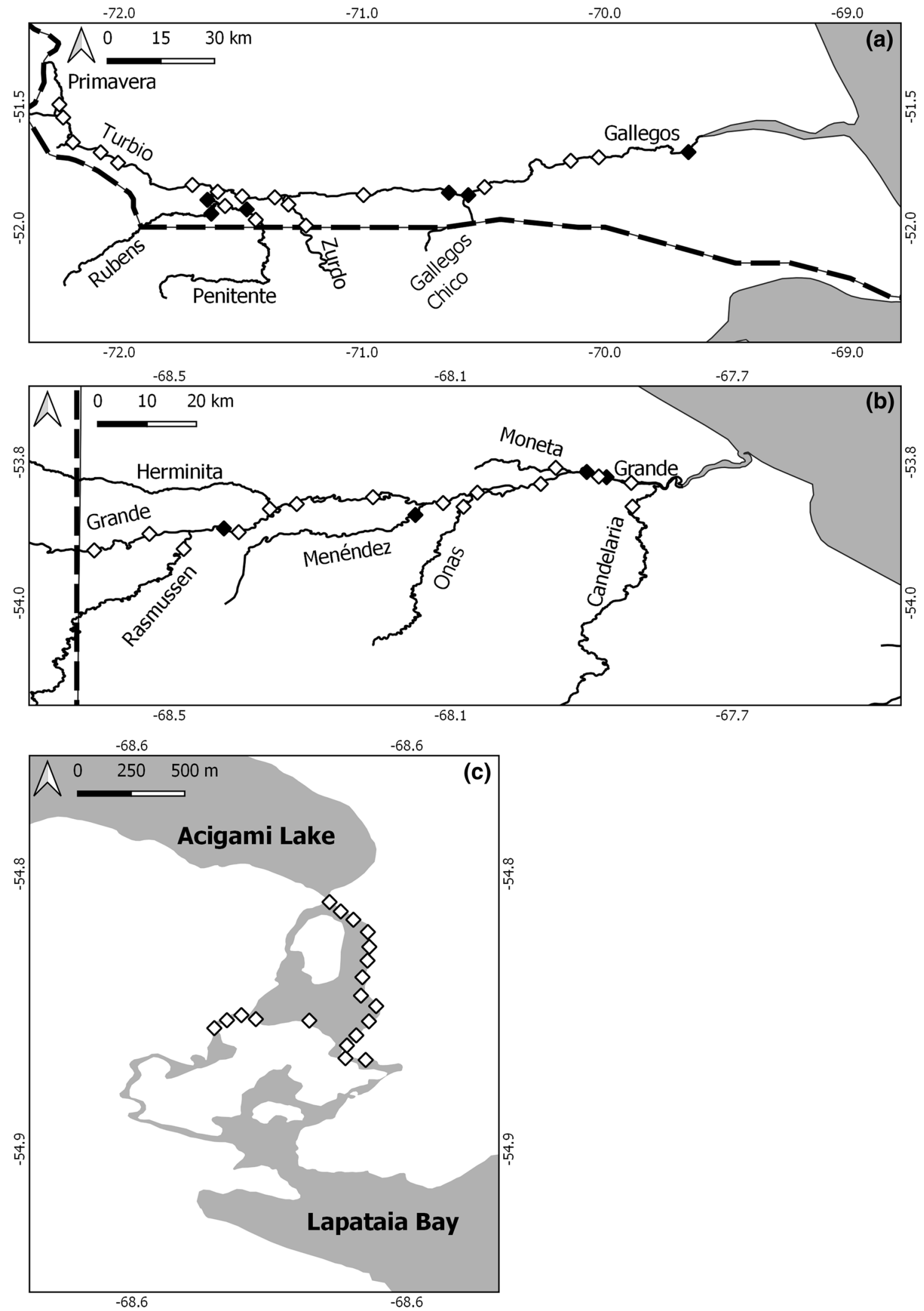

Fig. 3 Electrofishing survey sites at a Gallegos, b Grande, and $\mathbf{c}$ Lapataia basins. Black and white squares represent positive and negative sites for lamprey detection, respectively. Dashed lines indicate the Argentine-Chilean border 
resource PhyML 3.0 (Guindon et al. 2010). The substitution model was determined by the Smart Model Selection (SMS) option (Lefort et al. 2017) through the Akaike Information Criterion (AIC). For branch support, bootstrap was performed with 1000 replicates. BI was performed on MrBayes 3.2.7 software (Ronquist et al. 2012). The substitution model was determined with jModelTest 3.7 (Posada 2008). The parameters set in MrBayes were 30,000,000 generations, nst $=6$ and rates =invgamma; all other parameters were left on default settings. The branch support was expressed as a posterior probability in percentage. MP analysis was carried out with the software MEGA7 (Kumar et al. 2016) implemented with bootstrap, 1000 replicates, as branch support.

The genetic distances (Kimura 2-parameter distance) were estimated for the cyt b gene with the software MEGA7 (Kumar et al. 2016) and expressed as the proportion ( $p$ ) of nucleotide sites at which two sequences are different for the intraspecific and interspecific level. For this analysis, bootstrap was implemented as the variance estimation method with 500 replicates. For the intraspecific level, the haplotypes distinguished among the 14 sequences from the Gallegos and Grande basins, were compared. For the interspecific level, the genetic distances were investigated at two instances: (a) among species from the same genus, and (b) among species from different genera. For the former analysis, a bibliographic revision was used; for the latter, one sequence per genus from the phylogenetic analysis was used. All the geographical representatives for Geotria (one from this work, Chile, New Zealand, and Australia), were included.

\section{Morphometric analysis}

After electrofishing, lampreys were transported alive to the aquarium facilities of the Centro Austral de Investigaciones Cientificas. The total length (TL) and body weight (BW) were recorded to the nearest $0.1 \mathrm{~mm}$ and $0.01 \mathrm{~g}$, respectively, and then used to calculate the condition factor with the equation $C F=\frac{B W}{T L^{3}} \times 10^{6}$ (Ricker 1975). The developmental stage of lampreys was assigned following the seven metamorphosing stages of G. australis proposed by Potter et al. (1980). Besides, a total of 11 morphometric measurements were made following Bird and Potter (1979) (See Fig. 5 for details) and used to compare with the measurements of $G$. australis from Donnelly and Warren Rivers in south-western Australia reported by Potter et al. (1980).

\section{Results}

\section{Overview of the presence of lampreys in Patagonia}

Two diadromous lampreys have been described for Chilean Patagonia: G. australis and M. lapicida (Neira 1984; Renaud
2011). Neira (1984), reported a distribution map that shows the presence of both species along Chile from $33^{\circ} \mathrm{S}$ to $41^{\circ} \mathrm{S}$. The author also mentions the possible presence of G. australis on the South Pacific basins of the Chilean section of TDF. However, in this regard, we only found a study that reports the capture of one specimen of G. australis in a brook of the Chilean section of Tierra del Fuego (Norman 1937). The author gave no additional information on the location of the capture, nor if the brook was from a Pacific or Atlantic basin.

The first description of lampreys captured in Argentinian Patagonia was reported in Gallegos Basin by Eigenmann (1909), who mentioned the difficulties of finding lampreys in rivers of Patagonia. There is a more recent report on the presence of G. australis in the same basin at the estuary of the Gallegos River (Torres et al. 2006); however, no information on the number, size, or life stage of the individuals is given.

Ferriz et al. (1998) reviewed all publications of Patagonian fishes of Argentina, finding only one (unpublished) study performed specifically on lampreys (Nani 1950). In 2001, Azpelicueta et al. published a study on juveniles G. australis in Argentina, reporting the presence of this species in Negro and Chubut river basins. More recently, Aigo et al. (2008) and Cussac et al. (2016) made an extensive and interesting revision on the distribution of freshwater fishes of Patagonia reporting the presence of G. australis in four major basins of the region (Chubut, Gallegos, Negro, and Santa Cruz). Thus, taking into account only references where lampreys were captured and data on locations were provided, the presence of lampreys has been previously confirmed only in these four basins of Eastern Patagonia, extending from $41^{\circ} \mathrm{S}$ to $51^{\circ} \mathrm{S}$ (Table 3). Among these reports, that of Chubut River belongs to a juvenile individual found in a house water-pipe system in Chubut city (Table 3; Azpelicueta et al. 2001).

\section{Primers validation for lamprey detection}

The in silico analysis confirmed that both sets of primers showed specific alignment with G. australis mitochondrion genome (Accession Number NC_029404, New Zealand, Ren et al. 2016). Besides, no significant partial alignment was observed with any of the probable co-occurring species in the area. In vitro validation was achieved by Real-Time PCR using the target DNA (Lamprey 1 and 2, captured in Grande basin in 2015) and DNA of the species that have been reported at the area, as templates. Although several conditions were tested, it was not possible to obtain a positive result with the set of primers designed to amplify the cyt $b$ gene. In contrast, a 125 bp amplicon was obtained with the COI set of primers. Amplification was only observed when the template/s included the target DNA (+ C and Specificity Control); while no amplification was observed when 
Table 3 Streams with historical records on lampreys (reported as Geotria australis) captured in Argentina

\begin{tabular}{|c|c|c|}
\hline Stream data ${ }^{a}$ & Data on captures & Reference \\
\hline \multirow{3}{*}{$\begin{array}{l}\text { Negro River } \\
\text { Latitude at the mouth: } 41^{\circ} 01^{\prime} 23^{\prime \prime} \mathrm{S} \\
\text { Mean annual caudal: } 972 \mathrm{~m}^{3} / \mathrm{s}\end{array}$} & Summer and Winter/near the river mouth/Sandy beach/larval stage & Mac Donagh (1936) \\
\hline & $\begin{array}{l}\text { Summer and Winter } / 448 \mathrm{~km} \text { from the river mouth } / 14 \text { specimens } / \text { buried } \\
\text { about } 10-60 \mathrm{~cm} \text { in the muddy bottom/ juvenile stage/collected by hand }\end{array}$ & Azpelicueta et al. (2001) \\
\hline & $\begin{array}{l}\text { Spring/ } 688 \mathrm{~km} \text { and } 250 \mathrm{~km} \text { from the river mouth/low abundance/ larval } \\
\text { stage/collected by electrofishing, seine net }\end{array}$ & Alvear et al. (2007) \\
\hline \multirow{2}{*}{$\begin{array}{l}\text { Limay River (tributary of Negro River) } \\
\text { Latitude at the mouth: } 41^{\circ} 01^{\prime} 23^{\prime \prime} \mathrm{S} \\
\text { Mean annual caudal: } 736 \mathrm{~m}^{3} / \mathrm{s}\end{array}$} & $\begin{array}{l}693 \mathrm{~km} \text { from the mouth/137 specimens/larval stage/Collected by electrofish- } \\
\text { ing or by shovel and dip-nets }\end{array}$ & Neira (1988) \\
\hline & $\begin{array}{l}\text { Autumn/690 km from the river mouth/Sand and gravel/Collected by electro- } \\
\text { fishing }\end{array}$ & Baigún et al. (2002) \\
\hline $\begin{array}{l}\text { Chubut River } \\
\text { Latitude at the mouth: } 43^{\circ} 20^{\prime} 27^{\prime \prime} \mathrm{S} \\
\text { Mean annual caudal: } 35 \mathrm{~m}^{3} / \mathrm{s}\end{array}$ & One specimen/juvenile stage & Azpelicueta et al. (2001) \\
\hline $\begin{array}{l}\text { Santa Cruz River } \\
\text { Latitude at the mouth: } 51^{\circ} 35^{\prime} 43^{\prime \prime} \mathrm{S} \\
\text { Mean annual caudal: } 698 \mathrm{~m}^{3} / \mathrm{s}\end{array}$ & Autumn/195 and $55 \mathrm{~km}$ from the river mouth & Pascual et al. (2005) \\
\hline $\begin{array}{l}\text { Gallegos River and tributaries } \\
\text { Latitude at the mouth: } 51^{\circ} 35^{\prime} 43^{\prime \prime} \mathrm{S} \\
\text { Mean annual caudal: } 34 \mathrm{~m}^{3} / \mathrm{s}\end{array}$ & One adult and several individuals at larval stage ${ }^{\mathrm{b}}$ & Eigenmann (1909) \\
\hline
\end{tabular}

Data on captures include season/distance from the river mouth/number/habitat/developmental stage/fishing gear used. Not all data were available in all references

${ }^{a}$ Data from https://www.argentina.gob.ar

${ }^{\mathrm{b}}$ Reported as Geotria macrostoma galleguensis and Exomegas gill

all templates except for the target DNA were added to the reaction (non-Specific Control) (see Online Resource 1 for details). No significant interference at the $\mathrm{Ct}$ values was observed when all the DNAs were present, in comparison to the $\mathrm{Ct}$ values obtained in the $+\mathrm{C}$. The amplicons of the positive and specificity controls were sequenced, obtaining a $95 \%$ certainty of identity with $G$. australis COI gene. The COI set of primers was further used for the amplification of the environmental samples.

\section{eDNA-based lamprey distribution map and environmental sequences analysis}

Lamprey DNA was documented from 6 of the 21 sites sampled (Fig. 2; Table 2). The six positive sites corresponded to one tributary of the Gallegos basin in Santa Cruz Province and five river basins of TDF (Fig. 2; Table 2). An alignment was performed between the positive environmental amplicons, the positive amplification controls (genomic DNA of lamprey 1 and 2 as templates), and the COI gene sequence of $G$. australis (AN NC_029404; 1-1,554 bp). As a result, the environmental amplicons were a perfect match with lamprey 1 and 2 DNA, while these sequences were slightly different from the COI gene of G. australis with a 95-96\% certainty of identity (Online Resource 2).

\section{Phylogenetic analysis and genetic distances}

For the genetic analysis, eight lampreys from Gallegos basin and six lampreys from Grande basin were captured, while no lampreys were captured in Lapataia River (Fig. 3, Table 4). Fourteen cyt b sequences were obtained, and the consensus sequence matched with G. australis genome (AN NC_029404; New Zealand), showing 85\% certainty of identity. The phylogenetic analysis by the ML, MP, and IB methods resulted in trees with similar topologies. In the three of them, the cyt $b$ sequences of lamprey captured in this study (Argentinean lamprey) conforms a clade with G. australis with a high support value (Fig. 4).

We were able to distinguish five haplotypes $(\mathrm{H})$ among the 14 cyt b sequences. Haplotype 1 (H1) was the most frequent $(N=10)$ and was reported in both basins. A single sequence represented each of the additional haplotypes (H2-H5). The genetic distances for the cyt b sequences among haplotypes (intraspecific level) were $0.10-0.40 \%$ (Table 5a), and among the G. australis sequences were $0.20-1.90 \%$ (Table $5 b$ ). The genetic distances registered for the comparison between Argentinean lamprey and G. australis was $17.60 \%$ (Table 5b). After the bibliographic revision for lamprey species of the same genus, we observed a genetic distance of $0.20-5.70 \%$ (Table 6). Moreover, in the case of lamprey species from different genera, the registered value was $3.20-33.30 \%$ (Table 7). 
Table 4 Sites location, length and developmental stage of the lamprey captured in Gallegos and Grande basins

\begin{tabular}{lllllllll}
\hline Basin & River & Latitude & Longitude & $\begin{array}{l}\text { Distance from } \\
\text { mouth }(\mathrm{km})\end{array}$ & Length $(\mathrm{mm})$ & $n$ & Developmental stage $^{\mathrm{a}}$ & Date of capture \\
\hline Gallegos & Penitente & $51^{\circ} 55^{\prime} 11^{\prime \prime} \mathrm{S}$ & $71^{\circ} 29^{\prime} 43^{\prime \prime} \mathrm{W}$ & 216 & $120-128$ & 2 & Juvenile & April 2018 \\
& Rubens & $51^{\circ} 54^{\prime} 01^{\prime \prime} \mathrm{S}$ & $71^{\circ} 36^{\prime} 15^{\prime \prime} \mathrm{W}$ & 205 & 31 & 1 & Larval & April 2018 \\
& Gallegos_1 & $51^{\circ} 52^{\prime} 10^{\prime \prime} \mathrm{S}$ & $71^{\circ} 29^{\prime} 31^{\prime \prime} \mathrm{W}$ & 203 & 35 & 1 & Larval & April 2018 \\
& Gallegos_2 & $51^{\circ} 53^{\prime} 37^{\prime \prime} \mathrm{S}$ & $71^{\circ} 35^{\prime} 52^{\prime \prime} \mathrm{W}$ & 185 & 38 & 1 & Larval & April 2018 \\
& Gallegos Chico & $51^{\circ} 51^{\prime} 43^{\prime \prime} \mathrm{S}$ & $70^{\circ} 33^{\prime} 59^{\prime \prime} \mathrm{W}$ & 111 & 400 & 1 & Adult & April 2018 \\
& Gallegos3 & $51^{\circ} 41^{\prime} 16^{\prime \prime} \mathrm{S}$ & $69^{\circ} 39^{\prime} 20^{\prime \prime} \mathrm{W}$ & 13 & $30-35$ & 2 & Larval & April 2018 \\
Grande & Menendez & $53^{\circ} 51^{\prime} 42^{\prime \prime} \mathrm{S}$ & $68^{\circ} 08^{\prime} 23^{\prime \prime} \mathrm{W}$ & 40 & $111-113$ & 3 & Larval/Juvenile & April 2015 \\
& Grande_1 & $53^{\circ} 53^{\prime} 49^{\prime \prime} \mathrm{S}$ & $68^{\circ} 26^{\prime} 34^{\prime \prime} \mathrm{W}$ & 72 & 62 & 1 & Larval & April 2018 \\
& Grande_2 & $53.82^{\prime} 09^{\prime \prime} \mathrm{S}$ & $67^{\circ} 88^{\prime} 25^{\prime \prime} \mathrm{W}$ & 23 & 97 & 1 & Juvenile & April 2018 \\
& Grande_3 & $53^{\circ} 48^{\prime} 42^{\prime \prime} \mathrm{S}$ & $67^{\circ} 53^{\prime} 56^{\prime \prime} \mathrm{W}$ & 19 & $58-117$ & 4 & Larval/Juvenile & April 2018 \\
& Grande & $53^{\circ} 49^{\prime} 11^{\prime \prime} \mathrm{S}$ & $67^{\circ} 52^{\prime} 58^{\prime \prime} \mathrm{W}$ & 19 & $110-118$ & 2 & Juvenile & January 2019 \\
& Grande & $53^{\circ} 49^{\prime} 16^{\prime \prime} \mathrm{S}$ & $67^{\circ} 52^{\prime} 57^{\prime \prime} \mathrm{W}$ & 19 & $92-104$ & 2 & Juvenile & January 2020 \\
\hline
\end{tabular}

${ }^{\mathrm{a}}$ In accordance with Docker (2015)

\section{Morphometric analysis}

We captured four individuals from Grande River that showed the key characters corresponding to developmental stages 4-5 described by Potter et al. (1980) (Table 4): (1) Eye with dark pupil and gray/silver iris; (2) Lateral and transverse lips of oral aperture fused; (3) Body with a grayish sheen; and (4) Much of ventral surface silver. The morphometric measurements and the comparison of the results obtained here with data reported by Potter et al. (1980) are shown in Fig. 5. The most notorious differences were the higher length and weight, the shorter branchial length, and the shorter gap between dorsal fins.

\section{Discussion}

Our bibliographic review revealed three main issues in relation to lampreys in Eastern Patagonia: (1) that G. australis is the only lamprey species reported; (2) that there are reliable reports on their presence in only three rivers basins (not considering the report on Chubut river that corresponds to a unique individual found in a water-pipe system), and (3) that the study of lampreys in this region has not been widely addressed since we found only one published study specifically on lampreys (Azpelicueta et al. 2001).

The eDNA-based method developed here allowed us to identify lamprey-positive basins in southernmost South America. However, questions arose about the identity of the COI environmental amplicons, since the sequences were slightly different from the COI gene of G. australis. For this reason, we decided to capture lampreys for genetic analysis, using the cyt $b$ mitochondrial marker since there are a large number of available sequences in the databases. Besides,
Mateus et al. (2013) have demonstrated that this marker is a powerful tool for lamprey species identification, even in cases of cryptic species. The cyt b sequences of lamprey reported here, were quite different compared to G. australis genome ( $82-85 \%$ certainty of identity), while no such difference was observed with the COI environmental amplicon (95\% certainty of identity with G. australis genome). However, we must consider that this amplicon was only 80-90 bp. Also, the COI gene consists of several conserved regions alternate with variable regions (Kunal and Kumar 2013), and the fragment amplified in this study coincide with a conserved region.

Phylogenetic analysis revealed that Argentinean lamprey corresponds to a sister species to G. australis. Moreover, if we consider the percentage of genetic variation between Argentinean lamprey and G. australis, the value is surprisingly high (17.6\%), even higher than expected among species of the same genus (Table 6). This result is more consistent with the genetic distances between species of different genera, with a mean value of $22.4 \%$, as it can be observed from Table 7. The genetic distance analysis among the haplotypes of Argentinean lamprey agrees with an intraspecific variation if we compare it with the intraspecific values for $G$. australis from Chile, New Zealand, and Australia (Table 5a, b). Potter et al. (2015), suggested that Geotria would comprise at least two closely-related species rather than a single species. Our results suggest that the Argentinean lamprey may correspond not only to a new specific taxon but also that could represent a new monotypic genus in Geotriidae.

While this is the first report on genetic differences between lampreys from Argentina and G. australis from Chile and Australasia; several studies have previously reported morphological differences between them (Neira et al. 1988; Renaud 2011; Potter et al. 2015). In this study, 


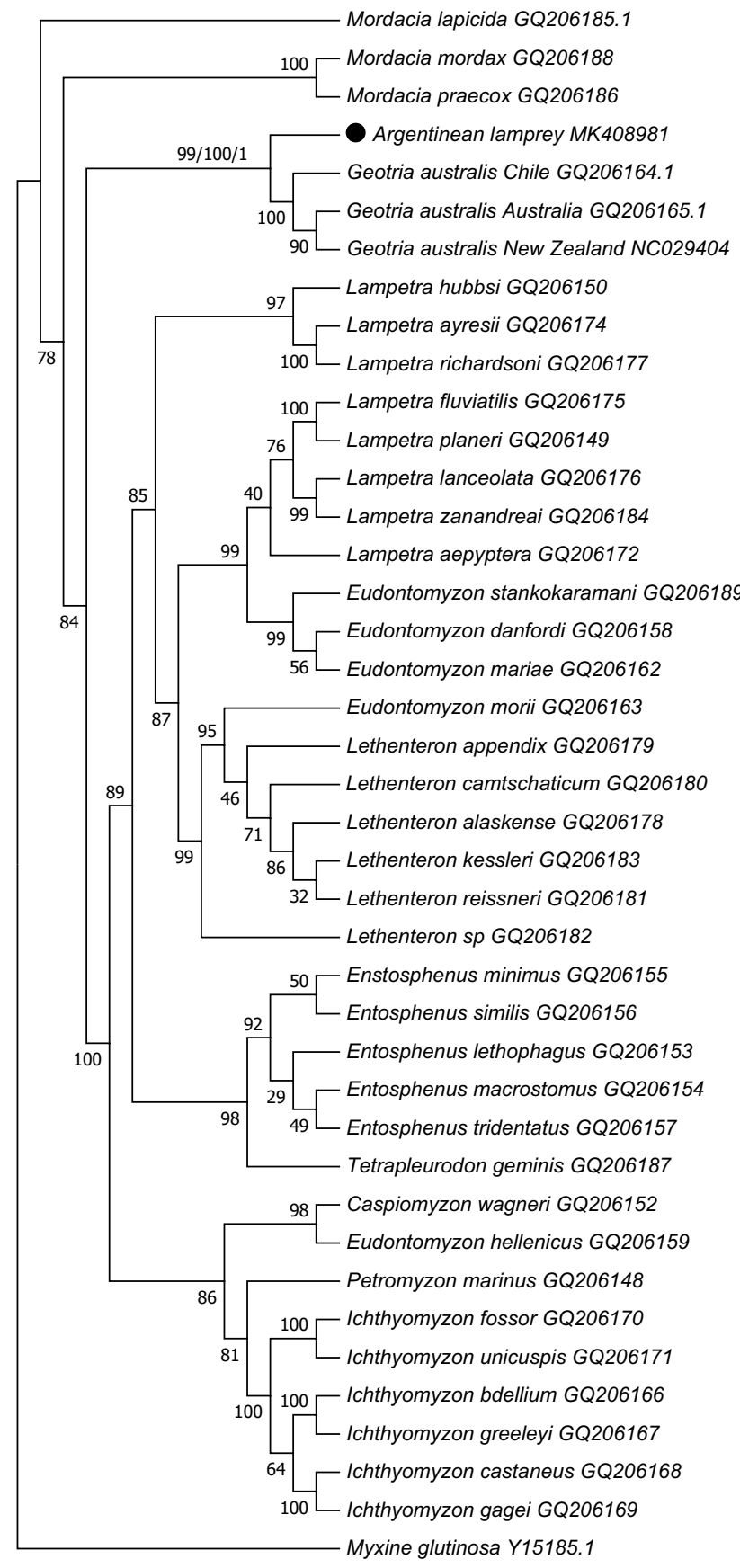

Fig. 4 Phylogenetic tree reconstruction of 41 taxa and 875 characters (cytochrome b gene) based on the Maximum Likelihood analysis. Maximum parsimony (MP) and Bayesian Inference (BI) yielded similar topologies. Bootstrap support values are indicated in the nodes. Myxine glutinosa was used as outgroup. Support values of MP (bootstrap support) and BI (posterior probability) are shown for the clade (Geotria australis + Argentinean lamprey; black dot)

we were able to analyze the morphology of only four lampreys in metamorphosis phase captured in Grande River in 2019 and 2020, since those captured in 2018 were not kept properly for the morphometric analysis. We found differences in some of the morphometric characteristics among Argentinean lampreys and data on juvenile G. australis reported by Potter et al. (1980) (Fig. 5). The most notorious differences were the higher length and weight of Argentinean lampreys. These results are in accordance with Azpelicueta et al. (2001), who reported lengths of $98.5 \pm 9.1 \mathrm{~mm}$ (mean $\pm \mathrm{SD} ; n=13$ ) in lampreys in juvenile stage captured in Negro River (Argentina), being these values also higher than those reported by Potter et al. (1980). Additionally, Neira (1984) mentions that $85-90 \mathrm{~mm}$ is the size in which $G$. australis begins its metamorphosis, while we collected lampreys at larval stage that were $113 \mathrm{~mm}$ in length in Grande basin (Table 4).

Regarding morphological differences, we believe that more specimens are needed to reach conclusions since we were not able to obtain a large number of lampreys in the field surveys. The lack of success in capturing lampreys has been previously reported for Argentinean Patagonia. In this sense, several authors have mentioned the difficulty of capturing individuals and the low abundance of lampreys in rivers flowing into the Atlantic Ocean (Azpelicueta et al. 2001; Alvear et al. 2007; Cussac et al. 2016). Maybe other fishing gears should be tested since electrofishing has proven not being successful for lamprey capture, even in an eDNApositive basin (Lapataia River).

Neira et al. (1988) reported several morphological differences between Geotria larvae from Argentina (Limay River) and G. australis larvae from Australia and Chile and suggested that gene exchange between them may be limited. Authors also suggested that Geotria from the Pacific and Atlantic coasts must show different migratory patterns, probably based on different currents and that these differences may have originated up to 6.5 million. years ago when a southern extension of the Andes cordillera between the tip of South America and the Antarctic peninsula restricted flow between the adjacent oceans. This hypothesis on the different currents and migration patterns is supported by the fact that M. lapicida does not extend from Chile around the base of South America into the rivers of Argentina (Hubbs and Potter 1971).

Finally, it is worth mentioning that G. australis is the sole lamprey species previously reported for Gallegos basin. However, all the individuals captured in this study from this basin were grouped as Argentinean lamprey, and the molecular evidence indicates that this lamprey corresponds to a new species, different from G. australis. Taking these data together, we believe that the species assignment of lampreys from rivers of Northern Patagonia, where G. australis is reported, should be revised. 
Table 5 (a) Genetic divergences (Kimura 2-parameter distance) between the haplotypes $(\mathrm{H})$ of Argentinean lamprey (below diagonal) and its standard deviation (above diagonal). (b) Genetic divergences (Uncorrected $p$ distances) between all the Geotria australis considered in this study and one sequence of Argentinean lamprey (MK408981) (below diagonal) and its standard deviation (above diagonal)

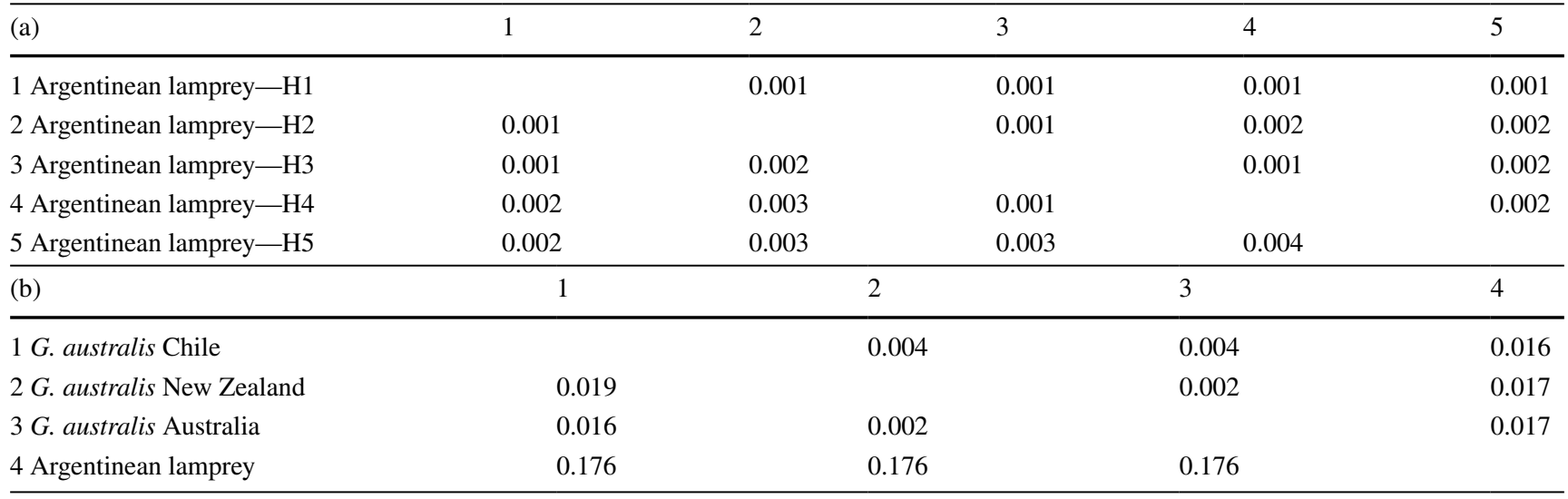

Table 6 Genetic divergences between species of the same genus compiled from the bibliography

\begin{tabular}{lll}
\hline Compared species & $\begin{array}{l}\text { Genetic divergence } \\
(\%)\end{array}$ & Source \\
\hline Lampetra planeri/L. lusitanica & $0.8-1.2$ & Mateus et al. (2013) \\
Lampetra planeri/L. auremensis & $0.3-0.9$ & Mateus et al. (2013) \\
Lampetra planeri/L. alavariensis & $0.4-1.1$ & Mateus et al. (2013) \\
L. pacifica/L. richardsoni & $2.8-3.2$ & Reid et al. (2011) \\
Lampetra spp./any known species & $2.3-5.7$ & Boguski et al. (2012) \\
Eudontomyzon hellenicus/E. graecus & 0.8 & Lang et al. (2009), Mateus et al. (2013) \\
Lethenteron kessleri/L. reissneri & 0.2 & Lang et al. (2009), Mateus et al. (2013) \\
Lethenteron appendix/L. alaskense & 0.9 & Lang et al. (2009), Mateus et al. (2013) \\
\hline
\end{tabular}

Table 7 Genetic divergences (Kimura 2-parameter distance) between lamprey species from different genera (below diagonal) and its standard deviation (above diagonal)

\begin{tabular}{llllllllllll}
\hline & & 1 & 2 & 3 & 4 & 5 & 6 & 7 & 8 & 9 & 10 \\
\hline 1 & Entosphenus minimus GQ206155 & & 0.021 & 0.022 & 0.017 & 0.011 & 0.011 & 0.022 & 0.015 & 0.006 & 0.015 \\
2 & Geotria australis GQ206165.1 & 0.288 & & 0.016 & 0.024 & 0.022 & 0.023 & 0.023 & 0.022 & 0.022 & 0.024 \\
3 & Argentinean lamprey MK408981 & 0.283 & 0.176 & & 0.024 & 0.023 & 0.022 & 0.022 & 0.022 & 0.022 & 0.023 \\
4 & Ichthyomyzon bdellium GQ206166 & 0.193 & 0.323 & 0.311 & & 0.017 & 0.016 & 0.022 & 0.015 & 0.017 & 0.017 \\
5 & Lampetra aepyptera GQ206172 & 0.104 & 0.308 & 0.292 & 0.194 & & 0.009 & 0.021 & 0.014 & 0.012 & 0.015 \\
6 & Lethenteron alaskense GQ206178 & 0.098 & 0.298 & 0.288 & 0.168 & 0.072 & & 0.022 & 0.014 & 0.012 & 0.015 \\
7 & Mordacia lapicida GQ206185.1 & 0.306 & 0.322 & 0.304 & 0.333 & 0.302 & 0.310 & & 0.022 & 0.015 & 0.023 \\
8 & Petromyzon marinus GQ206148 & 0.148 & 0.304 & 0.285 & 0.144 & 0.156 & 0.146 & 0.309 & & 0.014 & 0.014 \\
9 & Tetrapleurodon geminis GQ206187 & 0.032 & 0.294 & 0.271 & 0.185 & 0.114 & 0.106 & 0.297 & 0.152 & 0.015 \\
10 & Caspiomyzon wagneri GQ206152 & 0.148 & 0.314 & 0.284 & 0.189 & 0.166 & 0.157 & 0.322 & 0.134 & 0.151 & \\
\hline
\end{tabular}




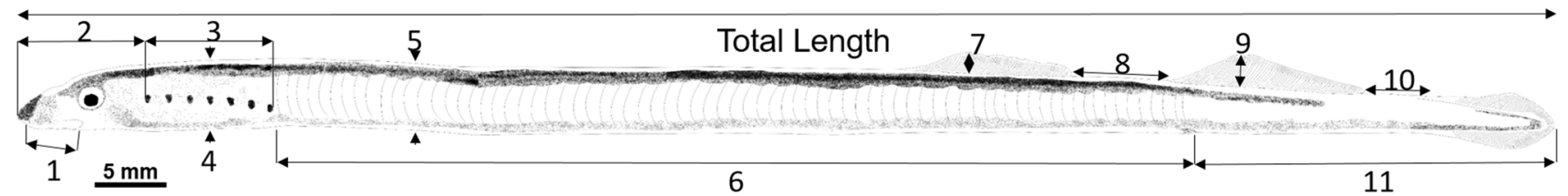

\begin{tabular}{lcccccc}
\hline \multicolumn{1}{c}{ Measurement } & \multicolumn{1}{c}{ Lamprey 1 Lamprey 2 Lamprey 3 Lamprey 4 } & Mean \pm SD & $\begin{array}{c}\text { Potter et al. (1980) } \\
\pm \text { 95 \% IC }\end{array}$ \\
\hline Total Length (mm)* & 118.3 & 110.8 & 92.3 & 104.4 & $106.5 \pm 11.0$ & $87-94$ \\
Weight (g)* & 1.67 & 1.45 & 0.85 & 1.27 & $1.31 \pm 0.35$ & $0.73-0.92$ \\
Condition Factor & 1.01 & 1.07 & 1.08 & 1.12 & $1.07 \pm 0.05$ & $0.95-1.2$ \\
1. Disc & 1.98 & 2.08 & 2.42 & 2.29 & $2.19 \pm 0.02$ & $1.9-2.3$ \\
2. Prebranchial length & 8.20 & 8.90 & 9.54 & 8.52 & $8.79 \pm 0.58$ & $7.6-8.9$ \\
3. Branchial length* & 7.60 & 8.10 & 8.62 & 8.58 & $8.23 \pm 0.48$ & $9.5-10.7$ \\
4. Branchial depth & 5.00 & 5.30 & 4.96 & 4.87 & $5.03 \pm 0.19$ & $4.6-5.1$ \\
5. Trunk depth & 4.70 & 5.20 & 4.72 & 4.82 & $4.86 \pm 0.23$ & $4.7-5.1$ \\
6. Trunk length & 60.90 & 62.20 & 56.90 & 58.29 & $59.57 \pm 2.41$ & $57.5-59.5$ \\
7. Height of 1st dorsal fin & 1.08 & 1.46 & 0.77 & 0.86 & $1.04 \pm 0.31$ & $0.75-1.45$ \\
8. Gap between dorsal fins* & 7.70 & 7.00 & 8.02 & 6.69 & $7.35 \pm 0.1$ & $7.8-8.8$ \\
9. Height of 2nd dorsal fin & 1.80 & 2.80 & 2.17 & 1.11 & $1.97 \pm 0.71$ & $1.4-2.2$ \\
10. Gap between 2nd dorsal & 4.50 & 3.80 & 3.03 & 3.93 & $3.82 \pm 0.60$ & $3.0-4.4$ \\
and caudal fins & 23.90 & 23.40 & 24.37 & 23.98 & $23.91 \pm 0.40$ & $23.0-24.7$ \\
11. Tail length & & & & & &
\end{tabular}

Fig. 5 Total length ( $\mathrm{mm})$, weight $(\mathrm{g})$, condition factor and body proportions (\% $\mathrm{TL}$ ) of lampreys captured in Grande River, and range of measurement data of Geotria australis from Donnelly and Warren Rivers in south-western Australia. All data correspond to individu-

Acknowledgements This work was funded by Universidad Nacional de Tierra del Fuego (PID-UNTDF B 06/2018), Agencia Nacional de Promoción Científica y Tecnológica (PICT 0759-2015), Consejo Nacional de Investigaciones Científicas y Técnicas (PIP 440). The authors thank Carolina Camilion and Noelia Paredes for their technical assistance.

\section{Compliance with ethical standards}

Conflict of interest The authors declare that they have no conflicts of interest.

Ethical approval All sampling procedures and animal manipulation followed the local regulation by the Institutional Committee for the Care and Use of Laboratory Animals of National University of San Martín, https://www.unsam.edu.ar/investigacion/cicuae.asp.

\section{References}

Aigo J, Cussac V, Peris S, Ortubay S, Gómez S, López H, Gross M, Barriga J, Battini M (2008) Distribution of introduced and native fish in Patagonia (Argentina): patterns and changes in fish assemblages. Rev Fish Biol Fish 18:387-408

Alvear P, Rechencq M, Macchi PJ, Alonso MF, Lippolt GE, Denegri MA, Navone G, Zattara EE, García Asorey MI, Vigliano PH (2007) Composición, distribución y relaciones tróficas de la als in developmental stages 4-5 following Potter et al. (1980). Asterisks show the most notorious differences between the morphometric measurements of lampreys captured in Grande River and Australia

ictiofauna del río Negro, Patagonia Argentina. Ecología Austral 17:231-246

Azpelicueta MM, Figueroa DE, Herrera R, Gosztonyi AE (2001) The macrophtalmia stage of Geotria australis Gray, 1851 (Petromyzontiformes: Geotridae) in Argentina. Neotrópica 47:81-84

Baigún C, López G, Dománico A, Ferriz R, Sverlij S, Delfino Schenke R (2002) Presencia de Corydoras paleatus (Jenyns, 1842), una nueva especie brasílica en el norte de la Patagonia (río Limay) y consideraciones ecológicas relacionadas con su distribución. Ecología Austral 12:41-48

Bird DJ, Potter IC (1979) Metamorphosis in the paired species of lampreys, Lampetra fluviatilis (L.) and Lampetra planeri (Bloch): 2. Quantitative data for body proportions, weights, lengths and sex ratios. Zool J Linnean Soc 65:145-160

Boguski DA, Reid SB, Goodman DH, Docker MF (2012) Genetic diversity, endemism and phylogeny of lampreys within the genus Lampetra sensu stricto (Petromyzontiformes: Petromyzontidae) in western North America. J Fish Biol 81:1891-1914

Bracken FSA, Rooney SM, Kelly-Quinn M, King JJ, Carlsson J (2019) Identifying spawning sites and other critical habitat in lotic systems using eDNA "snapshots": a case study using the sea lamprey Petromyzon marinus. L Ecol Evol 9:553-567

Carim KJ, Dysthe JC, Young MK, McKelvey KS, Schwartz MK (2016) A noninvasive tool to assess the distribution of Pacific lamprey (Entosphenus tridentatus) in the Columbia River basin. PLoS ONE 12:e169334

Chalde T, Nardi CF, Fernández DA (2019) Early warning: detection of exotic Coho salmon (Oncorhynchus kisutch) by 
environmental DNA and evidence of establishment at the extreme south Patagonia. Can J Fish Aquat Sci 76:2343-2349

Cussac VE, Fernández DA, Gómez SE, López HL (2009) Fishes of southern South America: a story driven by temperature. Fish Physiol Biochem 35:29-42

Cussac VE, Habit E, Ciancio J, Battini MA, Riva Rossi C, Barriga JP, Baigún C, Crichigno S (2016) Freshwater fishes of Patagonia: conservation and fisheries. J Fish Biol 89:1068-1097

Diaz BG, Monserrat MC, Tiberi PE (2017) Dinámica de caudales de superficie en la región hidrográfica del Río Gallegos (Santa Cruz, Argentina). In: XXVI Congreso Nacional del Agua, Córdoba, Argentina. pp 294-295

Docker MF (2015) Lampreys: biology, conservation and control, vol 1. Springer, New York

Eigenmann CH (1909) The fresh-water fishes of Patagonia and an examination of the Archiplata-Archelenis theory. Reports of the Princeton Expedition to Patagonia 1896-1899, III (I). Zoology 3:225-374

Evans NT, Olds BP, Renshaw MA, Turner CR, Li Y, Jerde CL, Mahon AR, Pfender ME, Lamberti GA, Lodge DM (2016) Quantification of mesocosm fish and amphibian species diversity via environmental DNA metabarcoding. Mol Ecol Resour 16:29-41

Fernandez S, Sandin MM, Beaulieu PG, Clusa L, Martinez JL, Ardura A, García-Vázquez E (2018) Environmental DNA for freshwater fish monitoring: insights for conservation within a protected area. PeerJ 6:e4486

Ferriz RA, López HL, Gómez SE (1998) Bibliografía de los peces continentales patagónicos. Aquatec 6:1-12

Gingera TD, Steeves TB, Boguski DA, Whyard S, Li W, Docker MF (2016) Detection and identification of lampreys in Great Lakes streams using environmental DNA. J Great Lakes Res 42:649-659

Goldberg CS, Pilliod DS, Arkle RS, Waits LP (2011) Molecular detection of vertebrates in stream water: A demonstration using rocky mountain tailed frog sand Idaho giant salamanders. PLoS ONE 6:e22746

Goldberg CS, Turner CR, Deiner K, Klymus KE, Thomsen PF, Murphy MA, Spear SF, McKee A, Oyler-McCance SJ, Cornman RS, Laramie MB (2016) Critical considerations for the application of environmental DNA methods to detect aquatic species. Methods Ecol Evol 7:1299-1307

Guindon S, Dufayard JF, Lefort V, Anisimova M, Hordijk W, Gascuel O (2010) New algorithms and methods to estimate maximumlikelihood phylogenies: assessing the performance of PhyML 3.0. Syst Biol 59:307-321

Habit E, Belk M, Victoriano P, Jaque E (2007) Spatio-temporal distribution patterns and conservation of fish assemblages in a Chilean coastal river. Biodivers Conserv 16:3179-3191

Hall TA (1999) BioEdit: a user-friendly biological sequence alignment editor and analysis program for Windows 95/98/NT. Nucl Acids Symp Ser 41:95-98

Hubbs CL, Potter IC (1971) Distribution, phylogeny and taxonomy. In: Hardisty MW, Potter IC (eds) The biology of lampreys, vol 1. Academic Press, London, pp 1-65

Iturraspe R, Urciuolo A (2007) Los recursos hídricos de Tierra del Fuego. In: Godoy Martinez C (ed) Patagonia Total. Antártida e Islas Malvinas, Barcel Baires, Buenos Aires, pp 733-754

Knebelsberger T, Dunz AR, Neumann D, Geiger MF (2014) Molecular diversity of Germany's freshwater fishes and lampreys assessed by DNA barcoding. Mol Ecol Resour 15:562-572

Koressaar T, Remm M (2007) Enhancements and modifications of primer design program Primer3. Bioinformatics 23:1289-1291

Kumar S, Stecher G, Tamura K (2016) MEGA7.0: Molecular evolutionary genetics analysis version 7.0 for bigger datasets. Mol Biol Evol 33:1870-1874
Kunal SP, Kumar G (2013) Cytochrome Oxidase I (COI) sequence conservation and variation patterns in the yellowfin and longtail tunas. IJBRA 9:301-309

Lang NJ, Roe KJ, Renaud CB, Gill HS, Potter IC, Freyhof J et al (2009) Novel relationships among lampreys (Petromyzontiformes) revealed by a taxonomically comprehensive molecular data set. In: Brown LR, Chase SD, Mesa MG, Beamish RJ, Moyle PB (eds) Biology, management, and conservation of lampreys in North America. American Fisheries Society Symposium, Bethesda, pp $41-55$

Laramie MB, Pilliod DS, Goldberg CS (2015) Characterizing the distribution of an endangered salmonid using environmental DNA analysis. Biol Conserv 183:29-37

Lefort V, Longueville JE, Gascuel O (2017) SMS: smart model selection in PhyML. Mol Biol Evol 34:2422-2424

Leprieur F, Beauchard O, Blanchet S, Oberdorff T, Brosse S (2008) Fish invasions in the world's river systems: when natural processes are blurred by human activities. PLoS Biol 6:e28

Mac Donagh E (1936) Sobre los peces del territorio de Río Negro. Instituto y Museo de la Universidad La Plata, Notas Museológicas pp 409-422

Maitland PS, Renaud CB, Quintella BR, Close DA, Docker MF (2015) Conservation of native lampreys. In: Docker MF (ed) Lampreys: biology, conservation and control, vol 1. Springer, New York, pp 375-428

Mateus CS, Alves MJ, Quintella BR, Almeida PR (2013) Three new cryptic species of the lamprey genus Lampetra Bonnaterre, 1788 (Petromyzontiformes: Petromyzontidae) from the Iberian Peninsula. Contrib Zool 82:37-53

McDowall RM (1988) Diadromy in fishes: Migrations between freshwater and marine environments. Croom Helm, London

McDowall RM (2002) Accumulating evidence for a dispersal biogeography of southern cool temperate freshwater fishes. J Biogeogr 29:207-219

Mizumoto H, Urabe H, Kanbe T, Fukushima M, Araki H (2017) Establishing an environmental DNA method to detect and estimate the biomass of Sakhalin taimen, a critically endangered Asian salmonid. Limnology 19:219-227

Moreno CA, Jara HF (1984) Ecological studies on fish fauna associated with Macrocystis pyrifera belts in the south of Fueguian Islands, Chile. Mar Ecol 15:99-107

Nani A (1950) Nota preliminar sobre la biología de la lamprea argentina Geotria australis Gray. Primer Congreso Nacional de Pesquerías Marítimas e Industrias derivadas, Mar del Plata, p 147

Nardi CF, Fernández DA, Vanella FA, Chalde T (2019) The expansion of exotic Chinook salmon (Oncorhynchus tshawytscha) in the extreme south of Patagonia: an environmental DNA approach. Biol Invasions 21:1415-1425

Neira FJ (1984) Biomorfología de las lampreas parásitas chilenas Geotria australis Gray 1851 y Mordacia lapicida (Gray, 1851) (Petromyzontiformes). Gayana Zoología 48:3-40

Neira FJ, Bradley JS, Potter IC, Hilliard RW (1988) Morphological variation among widely dispersed larval populations of anadromous southern hemisphere lampreys (Geotriidae and Mordaciidae). Zool J Linnean Soc 92:383-408

Niemeyer H (1982) Las hoyas hidrográficas de Chile. Informe Dirección General de Aguas, Santiago. https://bibliotecadigital.ciren .cl/handle/123456789/2348. Accessed May 2015

Norman JR (1937) Coast fishes. Part II. The Patagonian region. Disco Rep 16:1-150

Pascual M, Macchi P, Urbanski J, Marcos F, Riva Rossi C, Novara M, Dell'Arciprete P (2002) Evaluating potential effects of exotic freshwater fish from incomplete species presence-absence data. Biol Invasions 4:101-113 
Pascual MA, Riva Rossi CM, García Asorey M (2005) Un análisis preliminar de la fauna de peces del Río Santa Cruz y de los potenciales impactos de la construcción de las represas "Cóndor Cliff", y "La Barrancosa". https://www.gesa.com.ar

Pascual MA, Cussac V, Dyer B, Soto D, Vigliano P, Ortubay S, Macchi $P$ (2007) Freshwater fishes of Patagonia in the 21st Century after a hundred years of human settlement, species introductions, and environmental change. Aquat Ecosyst Health Manag 10:212-227

Posada D (2008) jModelTest: phylogenetic model averaging. Mol Biol Evol 25:1253-1256

Potter IC, Hilliard RW, Bird DJ (1980) Metamorphosis in the Southern Hemisphere lamprey, Geotria australis. J Zool 190:405-430

Potter IC, Fill S, Renaud CB, Haoucher D (2015) The taxonomy, phylogeny, and distribution of lampreys. In: Docker MF (ed) Lampreys: biology, conservation and control, vol 1. Springer, New York, pp 35-74

Raemy M, Ursenbacher S (2018) Detection of the European pond turtle (Emys orbicularis) by environmental DNA: is eDNA adequate for reptiles? Amphibia-Reptilia 39:135-143

Reid SB, Boguski DA, Goodman DH, Docker MF (2011) Validity of Lampetra pacifica (Petromyzontiformes: Petromyzontidae), a brook lamprey described from the lower Columbia River Basin. Zootaxa 3091:42-50

Ren J, Pu J, Buchinger T, Zhu X, Baker C, Li W (2016) The mitogenomes of the pouched lamprey (Geotria australis) and least brook lamprey (Lampetra aepyptera) with phylogenetic considerations. Mitochondrial DNA 27:3560-3562

Renaud CB (2011) Lampreys of the world. An annotated and illustrated catalogue of lamprey species known to date FAO Species Catalogue for Fishery Purposes. No. 5. FAO, Rome
Ricker WE (1975) Computation and interpretation of biological statistics of fish populations. Bull Fish Res Board Can 191:280-296

Ronquist F, Teslenko M, van der Mark P, Ayres DL, Darling A, Hohna S, Larget B, Liu L, Suchard MA, Huelsenbeck JP (2012) MrBayes 3.2: efficient Bayesian phylogenetic inference and model choice across a large model space. Syst Biol 61:539-542

Roy M, Belliveau V, Mandrak NE, Gagné N (2018) Development of environmental DNA (eDNA) methods for detecting highrisk freshwater fishes in live trade in Canada. Biol Invasions 20:299-314

Stem C, Margoluis R, Salfasky N, Brown M (2005) Monitoring and evaluation in conservation: A review of trends and approaches. Conserv Biol 19:295-309

Taberlet P, Bonin A, Zinger L, Coissac E (2018) Environmental DNA: for biodiversity research and monitoring. Oxford University Press, Oxford

Torres ER, Manero A, Vargas FA (2006) Listado sistemático y distribución temporal de los peces del estuario del río Gallegos (Santa Cruz, Argentina). Anales Instituto Patagonia (Chile) 34:59-64

Untergasser A, Cutcutache I, Koressaar T, Ye J, Faircloth BC, Remm M, Rozen SG (2012) Primer3 - new capabilities and interfaces. Nucleic Acids Res 40:e115

Publisher's Note Springer Nature remains neutral with regard to jurisdictional claims in published maps and institutional affiliations. 